\title{
Forensic Accounting: A Checkmate for Corporate Fraud
}

\author{
Lakshmi P., Ganesh Menon \\ University of Kerala, Kerala, India
}

\begin{abstract}
Forensic accounting gained importance due to increasing number of financial frauds and scams. This new area in accounting encompasses accounting, auditing, and investigative skills, thus emerged to detect frauds. They involve themselves in different areas like employee-related frauds, settlement and arbitrations, etc.. A forensic accountant has a financial sixth sense. Despite the fact that forensic accounting can bridge the gap between conventional accounting and auditing, this profession has not been able to gain the needed momentum due to some hassles. This paper tries to shed light on the theoretical concept, nature, practice, need, role of forensic accounting in preventing fraud, and the practical difficulties faced by forensic accountants. The study is based on information collected from interviewing practicing forensic accounting in India during 2011-12. The paper was able to assess the importance and rising scope of forensic accounting as a job. It also understood the practical difficulties they faced like lack of organized databases in Indian scenario which makes it difficult to access all needed information. Expectation level of the clients is very high and at times even unreasonable. This paper fulfills an identified need to study the important rising field of forensic accounting in India.
\end{abstract}

Keywords: forensic accounting, accounting frauds, auditing, internal audit, accounting scams

\section{Introduction}

The collapse of big business houses and numerous accounting scams plaguing the corporate world have necessitated the imperative need for a new perception of accounting and auditing that goes beyond numbers. Detecting fraud was considered to be a function of conventional accountants and auditors, till recently. Internal and external auditors were supposed to guard against frauds through their periodic audits. But auditors can only check the company's books of accounts for compliance of generally accepted accounting principles, auditing standards, and company policies. Moreover, public demands for change and subsequent regulatory reforms have transformed the entire scope of corporate governance. Nowadays, the top management is under lot of scrutiny. Such trends have the common goal of responsibly addressing investors' concerns about the authenticity of the financial reporting system. Thus, the need for a new strategy in accounting was felt to detect the fraud in companies/suspected fraudulent transactions. This area of accounting came to be known as "forensic accounting".

Forensic accounting is not an entirely new area in accounting. It has been there for years. Sherlock Holmes is considered to be the first ever forensic accountant. Some of the major corporate scandals like Enron, WorldCom cost the stakeholders trillions of dollars when the stock prices plummeted down badly affecting

Lakshmi P., Student, Department of Commerce, School of Business Management and Legal Studies, University of Kerala. Email: lakshmi.padmakumari@gmail.com.

Ganesh Menon, Professor, Department of Commerce, School of Business Management and Legal Studies, University of Kerala. 
investor confidence. These called for stricter financial governance. This led to the enactment of the Sarbanes-Oxley Act of 2002, also known as the "Public Company Accounting Reform and Investor Protection Act” in USA. This act is more commonly known as Sarbanes-Oxley, Sarbox, or SOX. The act covers issues such as auditor independence, corporate governance, internal control assessment, and enhanced financial disclosure. Sarbanes-Oxley began to draw the public's attention on what forensic accountants can do to uncover financial irregularities and track illegal financial activities. Since 9/11, forensic accountants have been playing a major role in tracking terrorists around the world. SOX-type laws have been subsequently enacted in Japan, Germany, France, Italy, Australia, South Africa, and Turkey.

In India, despite the fact that company accounts are prepared strictly and religiously as per the Indian Companies Act, many instances of mistakes necessitated the need for solving the problem of locating and reporting frauds. The Satyam Scam of 2009 which rocked the Indian corporate world also highlighted the need for employing the services of forensic accountants for detecting corporate frauds. Conventional auditing is like a watchdog of the financial system and the bloodhound is the forensic accountant. Public companies thus realized the need for adopting forensic accounting as part of a diligent internal control system to satisfy the market and regulatory needs for true and fair disclosures.

If statistics is to be believed, there is a big gap between the demand and supply of forensic accountants, giving them a coveted position. As per the study of India Forensic Center of Studies regarding Certified Forensic Accounting professionals, it was observed that the average annual salary of a forensic accountant is above Rs.8 lakhs, maximum being Rs.1.5 crores. There are multiple applications of forensic accounting in India like the accounting fraud investigations done by the investors, regulators like Securities and Exchange Board of India (SEBI), revenue authorities like Income Tax and Sales Tax. In addition, there are many companies employing forensic accountants for the investigation of employee-related frauds and corruption.

It is basically a general review paper based on information collected from interviewing practicing forensic accounting in India. The study was conducted in 2012. This paper tries to shed light on the theoretical concept, nature, practice, need, role of forensic accounting in preventing fraud and the practical difficulties faced by forensic accountants.

\section{Need for Forensic Accounting}

Increasing instances of misappropriation of corporate funds and the failure of statutory audit to prevent them, along with an increase in corporate crimes and frauds have put pressure to find a better way of exposing fraud in business world. A nationwide study conducted by Kessler International showed that 39\% of organizations in India have considered the need for a forensic accountant. The following are some of the factors that have given rise to forensic accounting:

(1) The existing conventional accounting or auditing practices are incapable of going beyond numbers and analyzing other hidden aspects of corporate fraud;

(2) There is no proper method to overcome issues of lobbying and collusion;

(3) There is no alternative mechanism to review auditor reports to ensure full authenticity and fairness;

(4) The inability of internal auditors to initiate action or to detect frauds in advance.

\section{Purpose of the Study}

The purpose of this paper is to spell out the concept, need, and role of forensic accounting in preventing fraud. More specifically, the paper tries to shed light on the following aspects: 
(1) The nature and theoretical concept of forensic accounting;

(2) The practice of forensic accounting;

(3) The usefulness of forensic accounting in strengthening the conventional accounting systems;

(4) The difficulties faced by forensic accountants.

\section{Meaning of Forensic Accounting}

"Forensic", according to the Webster's Dictionary, means "belonging to, used in or suitable to courts of judicature or to public discussion and debate".

According to American Institute of Certified Public Accountants, "Forensic accounting is the application of accounting principles, theories, and discipline to facts or hypotheses on issues in a legal dispute and encompasses every branch of accounting knowledge”.

Forensic accountants are trained to look beyond the numbers. They deal with the business reality of the situation. Forensic accountants often have to testify in an eventual trial in courts and have to provide an analysis of the accounting system comprehendible to court which will form the basis for discussion, debate, and ultimately dispute resolution. Forensic accountant should have in-depth knowledge of not only financial accounting, but also internal control systems, laws of the land, other institutional requirements, investigative proficiency, and interpersonal skills.

In short, forensic accounting integrates accounting, auditing, and investigative skills used for unearthing possible frauds in accounting. Insurance companies, banks, police forces, companies, and government agencies are major potential beneficiaries of forensic accounting.

\section{Scope of Forensic Accounting}

Forensic accounting involves two major components: litigation support and investigative accounting. Forensic accountants generally specialize at least in the two areas.

"Litigation services" recognize the role of an accountant as an expert consultant. "Litigation support" is primarily in the nature of accounting assistance for existing or pending litigations. It is mainly concerned with issues regarding the quantifying economic damages. It involves estimating the economic loss resulting from a breach of contract.

"Investigative accounting" is often associated with investigations of criminal matters. It would normally involve an investigation of employee theft, securities fraud, insurance fraud, kickbacks and proceeds of crime investigations.

In a nutshell, a forensic accountant investigates and scrutinizes financial evidence, develops computerized applications to help analyze and present financial evidence, consolidates the findings in the form of reports, exhibits and collections of documents, and assists in legal proceedings, including testifying in court as an expert witness and preparing visual aids to support trial evidence.

\section{Nature of Services}

The nature of services rendered by forensic accountants is:

(1) Detection of frauds committed by employees: Whenever employee-related frauds are suspected, forensic accountants are engaged to detect fraud, to trace the asset (if any) created out of fund embezzlement, to gather and review the evidence, and to interview the employee alleged to have embezzled the funds; 
(2) Criminal investigation: Where the matter under investigation involves financial implications, the services of a forensic accountant are utilized by the investigation department, law society, etc.. The report prepared by a forensic accountant comes in handy while preparing and presenting evidence;

(3) Settlement for outgoing partner: When the retiring partner feels that he/she has been unjustly settled with, he/she can challenge the settlement with the help of a forensic accountant, who can accurately assess the value of assets and liabilities due to his/her client;

(4) Cases relating to professional negligence: Forensic accountants also take up cases relating to professional negligence. Whenever there is a breach of Generally Accepted Accounting Standards (GAAS) or auditing practices or ethical codes of any profession, forensic accountants are required to quantify the loss resulting from such professional negligence or deficiency in service;

(5) Arbitration service: Forensic accountants render arbitration and mediation services to the business community, since they undergo special training in the area of alternative dispute resolution;

(6) Facilitating settlement regarding motor vehicle accident: As the forensic accountant is well acquainted with intricacies of laws relating to motor vehicles, and other relevant laws in force, his/her services become indispensable in measuring economic loss when a vehicle meets with an accident;

(7) Settlement of insurance claim: Insurance companies engage forensic accountants to have an accurate assessment of claims to be settled. Similarly, policyholders seek the help of a forensic accountant when they need to challenge the claim settlement as worked out by the insurance companies. A forensic accountant handles the claims relating to consequential loss policy, property loss due to various risks, fidelity insurance, and other types of insurance claims;

(8) Dispute settlement: Business firms engage forensic accountants to handle contract disputes, construction claims, product liability claims, and infringement of patent and trademarks cases, liability arising from breach of contracts and so on;

(9) Matrimonial dispute cases: Forensic accountants entertain cases pertaining to matrimonial disputes wherein their role is merely confined to tracing, locating, and evaluating any form of asset involved;

(10) Shareholders' and partnership dispute: These assignments often involve a detailed analysis of numerous years accounting records to quantify the issues in dispute. For example, a common issue that often arises is the compensation and benefits received by each of the disputing shareholders or partners;

(11) Business economic losses: Examples of assignments involving business economic losses include: contract disputes, construction claims, expropriations, product liability claims, trademark and patent infringements, and losses stemming from a breach of a non-competition agreement.

Thus, a forensic accountant can be of assistance in identifying the key documents available as evidence; preparing a detailed and balanced report on the quantum of evidence, written in a language easily understood by a lawyer or jury; examining the accounting reports submitted by counter parties and briefing legal counsels on the financial and accounting aspects of the case during pre-trial preparation.

\section{Attributes of a Forensic Accountant}

Far from being a stereotype accountant, the mind of a forensic accounting professional should be more of a private investigator with a financial sixth sense. The qualities required for becoming a successful forensic accountant can be categorized into professional qualities and personal qualities as under. 


\section{Professional Qualities}

A forensic accountant is expected to be a specialist in accounting and financial systems. Yet, as companies continue to grow in size and complexity, uncovering fraud requires a forensic accountant to become proficient in an ever increasing number of professional skills and competencies. Here are some of the broad areas of useful expertise for a forensic accountant:

(1) An in-depth knowledge of financial statements and the ability to critically analyze them. These skills help forensic accountants to uncover abnormal patterns in accounting information and recognize their source;

(2) A thorough understanding of fraud schemes, including but not limited to asset misappropriations, money laundering, bribery, and corruption;

(3) The ability to comprehend the internal control systems of corporations, and to set up a control system that assesses risks, achieves management objectives, informs employees of their control responsibilities, and monitors the quality of the programme so that corrections and changes can be made;

(4) Proficiency in computer and knowledge of network systems. These skills help forensic accountants to conduct investigations in the area of e-banking and computerized accounting systems;

(5) Knowledge of psychology in order to understand the impulses behind criminal behavior and to set up fraud prevention programmes and to motivate employees to strictly follow the legal and ethical accounting system;

(6) Interpersonal and communication skills, which aid in disseminating information about the company's ethical policies and help forensic accountants to conduct interviews and obtain crucially vital information;

(7) Thorough knowledge of company's governance policies and the laws that regulate these policies;

(8) Command of criminal and civil law, as well as, of the legal system and court procedures.

\section{Personal Qualities}

A capable forensic accountant should have the following qualities:

(1) Curiosity;

(2) Persistence;

(3) Creativity;

(4) Discretion;

(5) Organization;

(6) Confidence;

(7) Sound professional judgment.

A forensic accountant must be open minded and meticulous in scrutinizing the finer details of accounting. In addition, a forensic accountant must be able to listen carefully and communicate clearly, concisely, and effectively. They must have a keen understanding and a sixth sense for the facts and evidences that are not obvious, but likely to have an impact on a given transaction or activity.

\section{The Practice of Forensic Accounting}

Each forensic accounting assignment is unique. Accordingly, the actual approach adopted and the procedures performed will be specific to it. However, in general, forensic accounting assignments will include the steps detailed below: 
(1) Meet with the client: It is helpful to meet with the client to obtain an understanding of the important facts, players, and issues at hand;

(2) A conflict check: A conflict check should be carried out as soon as the relevant parties are established;

(3) Perform an initial investigation: It is often useful to carry out a preliminary investigation prior to the development of a detailed plan of action. This will allow subsequent planning to be based upon a more complete understanding of the issues;

(4) Develop an action plan: This plan will take into account the knowledge gained by meeting with the client and carrying out the initial investigation and will set out the objectives to be achieved and the methodology to be utilized to accomplish them;

(5) Obtain the relevant evidence: Depending on the nature of the case this may involve locating documents, economic information, assets, a person or company, another expert or proof of the occurrence of an event;

(6) Perform the analysis: The actual analysis performed will depend upon the nature of the assignment and may involve calculation of economic damages, summarizing of a large number of transactions, tracing of assets, performing of present value calculations utilizing appropriate discount rates, performing regression or sensitivity analysis, utilizing a computerized application such as a spread sheet, data base or computer model and utilizing charts and graphics to explain the analysis;

(7) Prepare the report: Often a report will be prepared by the forensic accountant that may include sections on the nature of the assignment, scope of the investigation, methodology used, and its limitations, findings and opinions. The report will include schedules and graphics necessary to properly support and explain the findings.

Forensic accountants also help to prevent fraud or proactively identify the potential financial problems. For example, a business may hire a forensic accountant to review financial records and processes so as to identify areas that might permit fraud or financial problems. This practice has become more common as accounting scandals have increased the demand for financial transparency. Problems that forensic accountants look for include: misleading financial reporting, personal gain of corporate insiders, and violations of the law or tax codes. Forensic accountants may serve as advisers to audit committees/investment analysts. Forensic accountants also conduct compliance audits. A compliance audit reviews how well an organization is complying with legal and regulatory guidelines.

Forensic accounting and forensic auditing are used as inter-related terms; however, there is a big difference between the two. "Forensic audit" is an expanded version of investigative audit. According to the Forensic Accounting Manual of India, forensic accounting is an analysis of the evidences and is done after the fraud is exposed whereas forensic audit is the auditing done for the detection of the frauds where the company or the stakeholder employing the forensic auditor is not aware whether the fraud exists or not.

\section{Forensic Accounting as a Profession}

Currently, Certified Forensic Accounting Professional is the only designation which helps the professionals to perform the assignments related to investigative accounting and litigation support. In order to become a Certified Forensic Accounting Professional, one needs to undergo the Uniform Examination and become a Certified Forensic Accountant. There are specialized certifications in the field of Information Technology, Banking, Insurance, and Money Laundering. 


\section{Merits of Forensic Accounting}

In India, internal audit is mandatory for all the companies having turnover above Rs. 2 crores according to the Companies Act 1956. In most of the cases, internal audit becomes a mandatory function and it becomes difficult to measure the performance of the internal auditors in terms of value addition. On the other hand, the forensic accountants are generally given the mandate to reduce or prevent the frauds and according to the reports of the companies like Riskpro Management Consulting Private Ltd., for every rupee invested in the forensic accounting function, the forensic auditors have saved at least 7 rupees for the company. This means a return on investment of $700 \%$. All the above makes forensic accounting a more coveted and valued service than conventional accounting or auditing.

\section{Practical Difficulties}

Forensic accounting is an emerging new area of accounting and as such, forensic accountants confront the following difficulties while practicing the profession:

(1) It is a premium service and not all the businesses can afford forensic accountants;

(2) Lack of organized databases in Indian scenario makes it difficult to access all needed information;

(3) Expectation level of the clients is very high and at times even unreasonable;

(4) Understanding level of the accountants about the true aspect of fraud detection is very dismal;

(5) Application of the technology in maintaining the books of accounts and their compatibility with the data analysis software is another hindrance in proper forensic accounting implementation;

(6) Additionally, the fraud perpetrators are far ahead of fraud fighters.

\section{Conclusion}

Forensic accounting is one of the best ever growing areas in accounting. It enhances the chances of success in the day-to-day life of a corporate firm by surmounting all the vexing and critical problems faced in the corporate world. Thus, various agencies fighting corruption worldwide will need to engage the service of forensic accountants to complement the efforts of other professionals in reducing fraudulent activities and installing fraud proof internal control system in corporate organizations. Forensic accounting will not prevent the frauds completely but it will help the system to reduce the frauds in the country. Today, according to the estimates of India Forensic Center of Studies, India is losing more than $\$ 76$ billion due to occupational frauds in India; this might be reduced drastically if more accountants are encouraged to specialize in forensic accounting.

Though the forensic accounting and auditing practice had commenced in the US as early as 1995, this branch of specialization is relatively new in India. While the majority of professional accountants in India have excellent analytical skills, they need to acknowledge that "forensic services" require "specialized" training as well as real-life "practical" corporate experience. The forensic accountant should be thoroughly exposed to the industry practices and should be able to integrate the same with transparent accounting practices. Forensic accountants should possess thorough knowledge of the various laws and legal processes involved. They should also have the communication skills to explain the complex financial information to lawyers, judges, and juries for a better understanding of the issues. Forensic accountants need to have sufficient expertise in tracking digitalized financial information and analyze the same to uncover any fraudulent transactions. In the days to come, the role of forensic accountant will be of paramount importance in corporate/public governance in ensuring transparency and fairness of accounting systems and preventing corporate frauds. 
Thus, the paper was able to assess the importance and rising scope of forensic accounting as a job. It also understood the practical difficulties they faced like lack of organized databases in Indian scenario which makes it difficult to access all needed information. Expectation level of the clients is very high and at times even unreasonable. Because of the chosen research approach, the research results may lack generalizability. Therefore, researchers are encouraged to test the proposed propositions further. The paper is useful for policymakers and practitioners as it highlights the reverent issue of accounting frauds and thus help make suitable amendments to the system to increase the scope of the forensic accountants in India to regulate the issue of accounting frauds. This paper fulfils an identified need to study the important rising field of forensic accounting in India.

\section{References $^{1}$}

Association of Certified Fraud Examiners. (2005). Fraud examiners manual. USA: Association of Certified Fraud Examiners, Inc..

Bhasin, M. (2007). Forensic accounting: A new paradigm for niche consulting. The Chartered Accountant. Retrieved from http://icai.org/resource_file/97231000-1010.pdf

Larry Crumbley, D. (2000). Journal of Forensic Accounting- Auditing, Fraud \& Taxation. USA: R.T. Edwards Inc..

Neve, B. (2012). Query regarding forensic accounting [email] (bhushan.neve@riskpro.co.in). April 23, 2012. Retrieved from https://mail.google.com/mail/ca/?shva=1\#inbox/136df5513bd56b04

Smith, R. T., \& Sefton, C. R. C. (1998). Accounting for damages: A framework for litigation support. Canada: CCH Canadian.

Zysman, A. (2012). Forensic accounting demystified. Retrieved from http://www.forensicaccounting.com/home.html\#one

\footnotetext{
${ }^{1}$ Disclaimer: This research is a purely conceptual one based on information and data collected. All the views and opinions expressed are meant to explain the concept more lucidly.
} 